methods were used as in the above, the only difference being that the outer solution instead of being pure salt solution was saturated with a narcotic. If we compare the above results with the pure potassium iodide solution and those with the same solution saturated with a narcotic, under the above-mentioned experimental conditions, we do not find significant differences in the fixation of iodine through the vitelline membrane. The differences found are within the range of the individual variations in the permeability of the vitelline membrane of different eggs. In the case of the albumin, in some of the above experiments but not in all, more of it was found in the outer solution than in an experiment with a pure water solution of the salt.

Thanks are due to Prof. Joachimoglu for advice during these investigations.

${ }^{1}$ Orru, A., Biol. Abstr., 14. 2, 211 (1940); Chem. Zentralbl., 1, 534 (1941); 2, $1462(1940)$.

\section{EXCAVATIONS OF A ROMAN HOUSE}

$\mathrm{D}^{\mathrm{n}}$ R. FELIX OSWALD has now carried further the story of his years of excavation at Margidunum*. So little remained of the buildings of the first-century camp after the Roman demolitions in Hadrian's reign that at first the excavator seemed faced with a hopeless task; but by the painstaking investigation of every foot of the area concerned, down to the level of the undisturbed subsoil, the greater part of the plan of a building identified as the Commandant's House was revealed. Unfortunately, the eastern rooms of this house lie beneath the Fosse Way, which crosses the centre of the camp at this point, and possibly a hypocaust may lie buried here, as none was found elsewhere.

The usual sequence of two buildings, one of timber and one of stone, was found, the first dating from the time of the foundation of the camp by Ostorius Scapula in A.D. 48, and destroyed during the Boudiccan rebellion, and the second erected, after the lapse of a few years, during the reign of Vespasian or Titus, and remaining in use until the end of the occupation of the camp. The surviving post-holes were too few for the plan of the timber building to be recovered, but the plan of the later house is of a type allied to that of houses known from other forts, and several of the plans of these are illustrated, drawn to the same scale for purposes of comparison. Stables may have existed to the north of the house, and an interesting feature is a pit contemporary with the timber building, which in view of a parallel at Hofheim, the excavator thinks may have been used for preserving oysters in salt water.

The major part of the report is devoted to the description, discussion and illustration of the pottery found on the site. The Terra Sigillata showed no very unusual features; but among the coarse wares of the earliest phase (Claudius-Nero), a large storejar with an impressed stamp of three stars above two rosettes on its lower half was an unusual discovery, and it is suggested that this may indicate a measure of quantity. The coarse ware of the succeeding phases shows considerable development, and includes frequent imitations of Terra Sigillata forms. Evidence was also found showing that some of the

* The Commandant's House at Margidunum. By Dr. Felix Oswald. Pp. 41 (17 plates). (University College, Nottingham, 1948.) 78. $6 d$. pottery of Vespasianic date was made at the Castor potteries. Any discoveries which help to tie down the dating of the products of these potteries are of particular interest owing to their increasingly widespread distribution. Altogether this report makes important additions to the mass of valuable comparative material with which Dr. Oswald has already provided us.

\section{SOUTH-EASTERN UNION OF SCIENTIFIC SOCIETIES}

\section{ANNUAL CONGRESS, 1948}

A $\mathrm{T}$ the invitation of the Mayor and the Corporation of Great Yarmouth, and with the co-operation of the Great Yarmouth Naturalists' Society, the SouthEastern Union of Scientific Societies held its fiftythird annual congress during June 14-19 at Great Yarmouth, under the presidency of Mrs. Jacquetta Hawkes. The Mayor, in his welcome to the Congress at the Town Hall, where accommodation was provided for meetings by the Corporation, said that those who were not versed in 'old buildings' could not appreciate the beauty of them, and that societies such as he was addressing opened the eyes to the reasons why such old buildings as those on the South Quay at Yarmouth should be preserved. Capt. Dannreuther inducted the president, and con. gratulated her upon being the first lady to hold the office since the foundation of the Union more than fifty years ago.

Mrs. Hawkes, in delivering her address upon "Archæology and the Present", said that two world wars had disturbed the faith in the certainty of progress in a way resembling the questioning of the story of Genesis by the theory of evolution. She believed that archæology provides a sense of comfort by comparisons, such as life in a palæolithic cave with life at Versailles or the compositions of Beethoven. The popularity of the subject is perhaps due to the solace obtained from the study of the solidity of the past compared with the flimsiness of the present and the uncertainty of the future. An education based on classical studies has been a great force in Britain, and it is of utmost importance to salve what is valuable and to adapt it to the changing conditions. Archæology can play its part by saving classical studies from exclusiveness and isolation. It can add intimacy and humanity to the classics to make them acceptable to a greater number.

Mrs. Hawkes said she believes that if the archæo. logical method, in the widest sense of the study of material things through all the periods, can become an accepted part of teaching, the distaste of people of all classes for vulgar architecture and badly designed utensils would lead to an improvement of our environment and thus to the general betterment of all. Archæology could display a vast array of cultures which would help us to decide how to search for new values and to teach us that mechanical gadgets are not essential to the fulfilment of valuable lives.

The Archæological Section of the Union was addressed by its president, Lieut.-Colonel S. E. Glendenning, on "Local Materials and Craftsmanship in Norfolk Buildings", and a paper on "Roman Britain as seen in the Yarmouth Neighbourhood" was read by Mr. P. E. Rumbelow, who also conducted 
an excursion to the Roman Station at Burgh Castle. Mr. H. J. Howard delivered the presidential address to the Botanical Section on "The Mycetozoa of Sanddunes and Marshland", and Mr. F. O. Whitaker's paper on "The Botany of the Cromer Forest Bed" was read. Joint excursions, with the Zoological Section, were conducted to Fritton Lake, Wheatfen Broad and Norwich.

The Geological Section elected Mr. C. D. Ovey as president, and his address was upon "Foraminifera in Stratigraphy with special reference to the Ecology of Living Forms". A paper was read on "The Geological and Archæological Problems of the Red Crag" by Mr. S. Hazzledine Warren, and Mr. J. E. Sainty gave a paper upon "The Geology of Norfolk". He also arranged and conducted successful excursions to the Norwich and Cromer areas in illustration of his views upon the formation of the district.

The Zoological Section's presidential address was given by Major Maxwell Knight on "The Study of Bird Pellets as a Subject of Interest and Instruction to Amateur Naturalists". A paper was read by Dr. Malcolm Smith on "Some Undetermined Points in the Life-Histories of the British Reptiles".

An evening conversazione was arranged by the Great Yarmouth, Lowestoft and Norwich Naturalists' Societies. A very successful Young Naturalists' evening was held at the Town Hall. Coloured Nature films, specially taken at the London Zoo by Mr. Douglas Fisher, were exhibited. The commentary on the first two, dealing with snakes, lizards, newts, frogs and toads, was given by Dr. Malcolm Smith, and that on the third, concerning the behaviour of the tarsier, was given by Major Maxwell Knight. The remainder of the evening was devoted to a naturalists' brains trust, the arrangements for which were in the capable hands of Major Maxwell Knight, who also acted as question master. His 'brains' were : Capt. T. Dannreuther, Mr. E. A. Ellis, Mr. David Seth-Smith and Dr. Malcolm Smith. Questions were selected from those sent in by schools in the area, a request having been made that they should be debatable rather than factual. Although admission was limited by the issue of tickets, more than a hundred sdditional young people got into the hall, which, besides giving encouragement to the organisers, should also give hope to those whose theme is the rejuvenation of the local natural history societies. The question master suggested to the delegates present that each of the seventy societies affiliated to the Union might, with advantage, arrange similar evenings.

After the general assembly, the discussion on "The Functions and Organisation of Local Societies", in continuation of that initiated by the British Associa. tion, was opened by Mr. G. Gosnell.

The next congress of the Union will be held at Canterbury during Easter 1949.

\section{SMITHSONIAN INSTITUTION}

\section{ANNUAL REPORT}

T HE report of the Secretary of the Smithsonian Institution, Washington, D.C., for the year ended June 30,1947 , which includes reports on the newly established National Air Museum and on the Canal Zone Biological Area, recently placed under the administration of the Institution, records the resumption and, in some directions, expansion of much of the normal research and field-work suspended during the War. Accessions to the National Museum are back to pre-war levels, and the International Exchange Service has considerably reduced the accumulation of material for foreign exchange built up during the war years, and the service will soon be again on a current basis. The two greatest needs of the Institution are additional staff and more building space.

Under the Canal Zone Biological Area Advisory Board, a wide range of studies and tests has bsen carried out under tropical conditions. Those in progress include an extensive organisation for testing the proofing of wood to termites, the tropical deterioration of plywoods, textiles, and packaging containers, and the effect of fungi on optical glass. Some four hundred publications have been issued on research carried on here in entomology, forestry and medicine with special reference to the control of termites, fruit flies and mosquitoes.

Appended to the secretary's report is the Financial Report of the Executive Committee of the Board of Regents, as well as separate reports on the National Museum, the National Gallery of Art, the National Collection of Fine Arts, the Freer Gallery of Art, the Bureau of American Ethnology, the International Exchange Service, the National Zoological Park, the Astrophysical Laboratory, the National Air Museum, the Canal Zone Advisory Board, the library and publications.

The report from the National Museum refers to the resumption of investigations of fifteenthcentury historic Indian village sites and some of the early Spanish settlements in the West Indies, to the continuation of the survey of the fishery resources of Guatemala, a botanical survey of St. Vincent, and to field work on the lower cryptogams as part of a biological survey of the Patuxent Research Refuge. Systematic researches under the Bureau of American Ethnology recorded during the year include the River Basin Surveys, aimed at recovering such archæological and palæontological information and materials as will be lost through the construction of dams and creation of large reservoirs in many of the river valleys of the United States. Papers prepared for publication deal with the State names of Mexico, the province names of Canada, and the detailed ethnographical description of the projecting rocks and islands off the coast of California, while a bibliographic project has been initiated having as objective the compilation of an annotated, fully indexed bibliography covering the descriptive, geographical and other scientific literature on the Arctic from the earliest historical writings to those of the present time. A roster of Arctic specialists is also being compiled which will afford a comprehensive record of the experience and specialized knowledge of scientific men, explorers, writers, and Arctic residents who possess first-hand information of value concerning the Arctic and sub-Arctic regions. A joint expedition with the National Geographic Society made an archæological survey of the Pacific coast of the State of Chiapas, Mexico, and the Viru Valley Expedition attempted to survey thoroughly a single valley of the Peruvian coast as a living unit through some three thousand years, including archæological, geographical and modern community studies.

The report on the National Zoological Park, in addition to listing accessions during the year, gives a complete list of animals in the Park at June 30 , 